\title{
Salmonella Serotype Enteritidis
}

National Cancer Institute

\section{Source}

National Cancer Institute. Salmonella Serotype Enteritidis. NCI Thesaurus. Code C86919.

Any bacterial organism that can be assigned to the genus Salmonella with serotype Enteritidis. 